From the Department of Surgery, College of Veterinary Medicine and Small Animal Clinic MEVET, Helsinki, Finland.

\title{
Biodegradable Implants in the Fixation of Physeal Fractures in Cats and Dogs
}

\author{
By P. Axelson, A. Mäkelä, S. Vainionpää, M. Mero and P. Rokkanen
}

\begin{abstract}
Axelson, P., A. Mäkelä, S. Vainionpää, M. Mero and P. Rokkanen: Biodegradable implants in the fixation of physeal fractures in cats and dogs. Acta vet. scand. 1988, 29, 477-484. - In a preclinical and a clinical study physeal fractures of cats and dogs were fixated with biodegradable implants. The preclinical part consisted of 4 cats with experimental physeal fractures of the distal femurs and the clinical part of 6 cats and 8 dogs with different physeal fractures. All fractures were fixated with selfreinforced polyglycolic acid (PGA) implants of different sizes. No external support was applied after the fixation. All cats and dogs used their operated legs during the first postoperative week and they could walk without lameness in 6 weeks. The fracture healed without delay or malformations. The retardations of the growth of the physeal regions were considered minimal.
\end{abstract}

small animal surgery; absorbable implants; epiphysiolysis.

\section{Introduction}

Since Hales in 1727 found out that the growth of the long bones took place in the ends of the bones many investigators have shown interest in the secrets of the epiphyseal plates. Despite numerous theories and a lot of experimental work it took more than 200 years before Campbell et al. made the basic experimental study for the modern opinion of the epiphyseal plate (Campbell et al. 1959). He used 65 growing dogs for 117 operative procedures through the distal femoral and radial epiphyses. The conclusions of the study indicated that empty holes, metallic pins and homogenous bone-grafts, more than $3 \mathrm{~mm}$ in diameter and all screws caused premature closures of the physeal plates and/or malformations of the epiphyses. The degree of the retardation of growth was roughly proportional to the cell number destroyed, to the firmness of the rigid bridge between the epiphysis and the metaphysis (bone or metal) and to the growth potential left in the physeal plate at the time of the accident.

Salter \& Harris classified the physeal fractures into 5 groups depending on the anatomical differences of the fracture lines (Salter $\&$ Harris 1963). He also studied the principles of the treatment of physeal fractures and their prognoses. The groups I and II had better prognoses than III, IV and V provided they were properly treated.

In the handbooks and manuals of small orthopaedics different techniques are described to fixate physeal fractures. The most common technique is to use 2 or more Kirschner wires of $1.5 \mathrm{~mm}$ in diameter perpendicularly through the epiphyseal plate. They are small enough not to destroy many growing cell 
columns in the growth plate and smooth enough for the epiphysis to glide along the pins as the bone is growing. Crosspinning or nailing and the use of tension wire and screws are not recommendable because they will lead to the premature closure of the physeal plate. All metal implants have to be removed in 3-4 weeks after the fixation because of their retarding effect on the physeal plate and because they sometimes tend to loosen from the surrounding bone tissue and "eat" themselves through the soft epiphyses into the joints (Bojrab 1983, Brinker et al. 1984, Arnoczky 1985).

A biodegradable implant (biorod) of selfreinforced polyglycolic acids (PGA) was developed to fixate metaphyseal fractures (Törmälä et al. 1984). This implant (Biofix $\left.{ }^{\circledR}\right)$ was used in clinical veterinary studies to fixate cancellous bone fractures of cats and dogs (Axelson et al. 1988). The effect of a penetrating biodegradable implant on the physeal plate was studied by Mäkälä et al. (1987). The implant was made of polyglactin 910 (PGA/PLA) and resembled the biorod of PGA. The force of the growth broke the polyglactin biorod of $3.2 \mathrm{~mm}$ in diameter at the level of the growth plate as early as 3 weeks after the operation, which allowed the growth cartilage to regererate. A slight narrowing of the physeal plate was seen only after 12 weeks, when using a biodegradable PGA/PLA implant. A transepiphyseal drill hole of equal size on the control side caused significant narrowing of the epiphyseal cartilage in 3 weeks (Mäkelä et al. 1987).

As the results of the experimental studies of physeal fracture fixations with this biodegradable PGA implant of rabbits were promising a study was made to fixate physeal fractures of cats and dogs with the same implant.

\section{Materials and methods}

Preclinical study

In the preclinical study 4 cats 26 weeks of age and weighing over $2 \mathrm{~kg}$ (mean $2.2 \mathrm{~kg}$ ) were used. The cats anaesthetized with intramuscular xylazin hydrochloride (Rompun ${ }^{\circledR}$, Bayer) $2 \mathrm{mg} / \mathrm{kg}$, diazepam (Diapam ${ }^{\circledR}$, Orion) $2,5 \mathrm{mg} / \mathrm{kg}$ and ketamine hydrocloride (Ketalar ${ }^{\circledR}$, Parke Davis) $10 \mathrm{mg} / \mathrm{kg}$. Preoperatively, the cats were given 250000 IU procain penicillin intramusculrly. The right knee was shaved and scrubbed with NeoAmisept ${ }^{\circledR}$. A medial parapatellar incision was made on the right knee. The patella was dislocated laterally and the distal portion of the right femur was exposed. The epiphyseal line was located and the periosteum was incised transversely just above the epiphyseal line in the anterior half of its periphery. By grasping firmly the epiphysis and the metaphysis and by bending the epiphysis into various and simultaneously rotating it internally, epiphyseal separation could be achieved invarably. The separation required somewhat varied force. Radiographs of the right femur were taken in the anteroposterior and lateral projections. After accurate reduction a drill hole of $1.0 \mathrm{~mm}$ in diameter was made in both femoral condyles through the articular surfaces, one in each parallel to the long axis of the femur and across the growth plate and through the metaphyseal cortex. Two selfreinforced PGA biorods of $1.0 \mathrm{~mm}$ in diameter and $25 \mathrm{~mm}$ in length were driven into the drill-holes, one in each. With the biorods a firm fixation of the physeal fractures was always achieved. The patella was replaced and in the incision was closed in layers by 3-0 PGA (Dexon ${ }^{\mathbb{B}}$ ) sutures. Radiographs of both femurs were taken postoperatively in the anteroposterior and lateral projections. The cats were returned to their cages and they were given normal food and care. Radiographs of the right fe- 
mur were taken at the follow-up times after $1,3,7,9$ and 18 weeks. The cats were sacrificed by an overdose of xylazinhydrochloride (Rompun ${ }^{\mathbb{B}}$ ) and pentobarbital sod (Mebunat ${ }^{\mathrm{B}}$ ).

After sacrifice both femurs were dissected and their langth was measured. Radiographs of both femurs were taken in the anteroposterior and lateral projections. Visual observations were made with regard to signs of infection or deformities. For the histological examination the specimens were fixed in $70 \%$ alcohol and embedded in methylmetacrylate (Schenk 1965). Five micrometer thick longitudinal sections were cut with a microtome and stained by the MassonGoldner method (Goldner 1938).

\section{Clinical study}

The clinical part of this study consisted of 6 cats and 8 dogs with physeal fractures as ordinary patients from the Department of Surgery of the College of Veterinary Medicine and Small Animal Clinic MEVET, both in Helsinki, Finland. The average weight of the cats was $3.3 \mathrm{~kg}$ and of the dogs $11.6 \mathrm{~kg}$. The average age of the cats was 7 months and of the dogs 6 months (Table 1).

Clinical findings: All patients had various traumatic anamneses and they had lameness of the fourth degree (on a scale of $0-4$ ). Their general condition was slightly altered, probably due to the pain. The injured sites were remarkably swollen and painful. Clinical instability could be found in the regions of trauma.

Radiographic findings: The injured regions of the patients were radiographed in at least anteroposterior and lateral projections. Total dislocations were found in all physeal fractures except in 4 cases, all crista tibiae injuries. The fragments were held in place by the straight patellar ligament but showed a larger space between the crest and the tibia compared to the contralateral limb (traction type of physeal fracture).

The physeal fractures were distributed in the following way (see Table 1). Six of these physeal fractures were classified as Salter I fractures and 4 as Salter II. Four physeal fractures were of the traction type (all fractured tibial crests).

Table 1. The list of the patients with physeal fractures fixated with biodegradable implants of selfreinforced PGA.

\begin{tabular}{ccrccll}
\hline Case & Animal & Weight & Age & Salter & Biorod & Physeal fractures of \\
\hline 1 & cat & $3 \mathrm{~kg}$ & $4 \mathrm{~m}$ & II & 2 mini & Distal Radius \\
2 & dog & $10 \mathrm{~kg}$ & $4 \mathrm{~m}$ & II & mini & Distal Radius \\
3 & dog & $6 \mathrm{~kg}$ & $6 \mathrm{~m}$ & I & small & Femoral Head \\
4 & cat & $3 \mathrm{~kg}$ & $7 \mathrm{~m}$ & I & small & Distal Femur \\
5 & cat & $3 \mathrm{~kg}$ & $6 \mathrm{~m}$ & I & 2 mini & Distal Femur \\
6 & cat & $4 \mathrm{~kg}$ & $7 \mathrm{~m}$ & i & small & Distal Femur \\
7 & cat & $4 \mathrm{~kg}$ & $12 \mathrm{~m}$ & I & small & Distal Femur \\
8 & dog & $15 \mathrm{~kg}$ & $7 \mathrm{~m}$ & II & small & Distal Femur \\
9 & cat & $3 \mathrm{~kg}$ & $7 \mathrm{~m}$ & I & small & Distal Femur \\
10 & dog & $2 \mathrm{~kg}$ & $6 \mathrm{~m}$ & II & mini & Proximal Tibia \\
11 & dog & $7 \mathrm{~kg}$ & $4 \mathrm{~m}$ & T & mini & Tibial Crest \\
12 & dog & $20 \mathrm{~kg}$ & $6 \mathrm{~m}$ & $\mathrm{~T}$ & 2 mini & Tibial Crest \\
13 & dog & $8 \mathrm{~kg}$ & $7 \mathrm{~m}$ & $\mathrm{~T}$ & mini & Tibial Crest \\
14 & dog & $25 \mathrm{~kg}$ & $6 \mathrm{~m}$ & $\mathrm{~T}$ & small & Tibial Crest \\
\hline
\end{tabular}


Surgery: All cases were operated on within 3 days after the accident. The sedation was made by giving $20 \mu \mathrm{g}$ medetomidim (Domitor $^{\circledR}$, Pharmos) intramuscularly.The anaesthetic procedure was induced by giving sodium pentothal (5\%) intravenously. After intubation the patients were connected to the inhalation system of $2 \%$ halothane with oxygen and air.

Shaving, cleaning and the antiseptic care were performed in standard procedures of the clinics.

The exposure were chosen according to Piermattei \& Greeley (1979). The sizes and the numbers of the biorods were decided from the preoperative radiographs. After the exact reduction of the fragments, a drill matching the biorod chosen (Table 2) was used to drill the channel through the epiphysis and the physeal plate into the metaphysis. Attempts were made to put the starting point of the drilling beside the atricular cartilage, if possible. The direction of the channel was perpendicular to the physeal plate and the depth was decided by the length of the biorod chosen. The midpoint of the biorod had to align the physeal plate, with exceptions of the crista tibiae fixations (Fig. 1). The biorod was driven into the channel with help of a specially made applicator (Axelson et al. 1988). In 2 cases with a fractured tibial crest additional fixation with an osteosuture of PGA (Dexon ${ }^{\mathbb{B}}-1$ ) was used. The closing of the operative wound was made in the standard manner using 3-0 PGA sutures (Dexon ${ }^{B}$ ).

Table 2. Sizes of Biofix ${ }^{\circledR}$.

Large: $\quad 4.5 \mathrm{~mm} \times 70 \mathrm{~mm}$

Medium: $4.5 \mathrm{~mm} \times 50 \mathrm{~mm}$

Small: $\quad 3.2 \mathrm{~mm} \times 50 \mathrm{~mm}$

Mini: $\quad 2.0 \mathrm{~mm} \times 30 \mathrm{~mm}$

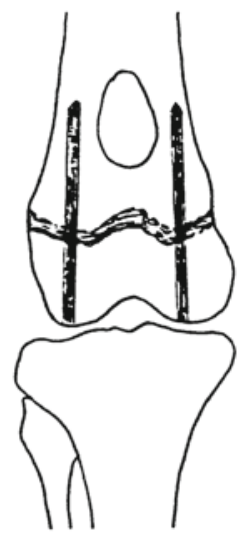

a

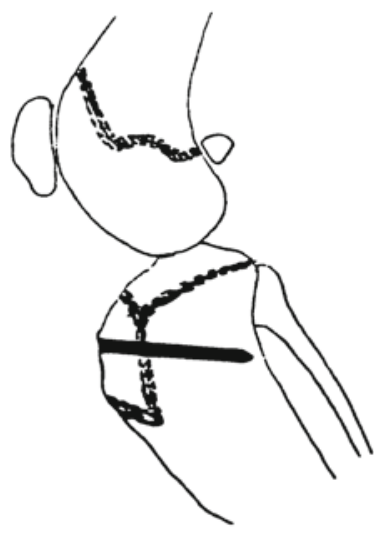

b
Figure 1. Schematic pictures of the application of the biorod in a physeal fracture of a distal femur (a) and a tibial crest (b).

Postoperative proceedings: Postoperatively, the operated limb was put into a socalled Robert Jones bandage without any external splinting. The patients were allowed to walk in their operated limbs immediately after the operation.

Controls: Clinical and radiographic controls were made 1, 3 and 6 weeks postoperatively and there was final control of the fractured distal femurs when all the physeal plates had closed.

The clinical examination included the estimation of the swelling (edema) of the operated are snd the classification of the degree of lameness (on a scale 0-4). The movements of the nearby joint of the operated physeal plate compared to the contralateral one were estimated in the final examination.

The evaluation of the radiographs included the estimation of the dislocation and the angulation of the fragments, the thickness of the physeal plate, the callus formation and the bone radiodensity around the implants. The length of the operated femurs and the 
contralateral ones were measured from the final radiographs taken of the cases with distal femoral physeal fractures when all the physeal plates were closed.

\section{Results \\ Preclinical study}

All 4 cats were able to walk on their operated limbs without difficulties in 3 weeks after the operation. There were no patellar dislocations or infections in the operated knees. Radiographs showed normal features of the right distal femurs at the follow-up times of 1, 3, 7 and 9 weeks. After 18 weeks the closure of the distal femoral growth plates was seen on both knees.

Fixations of the physeal fractures of the distal femurs with two PGA pins caused minimal shortening $(1.3 \mathrm{~mm}=1.2 \%)$ of the operated femurs in three out of four cases. The fourth case had equally long femurs.

Histological examination after 18 weeks showed the union of the distal femoral plate in 2 cases on the operated side. The only remnants of the physeal cartilage were found at the periphery of the growth plate. The control side showed normal features of the palisading structure of the growth plate. Only a few tiny bone bridges connecting the epiphysis to the metaphysis indicated the union of the growth plate taking place in the immediate future. In the other 2 cases the growth showed normal features on both sides.

\section{Clinical study}

All 14 patients started to use their operated limbs during the first week after the operation. Twelve patients $(85 \%)$ could without lameness in 3 weeks and the other 2 within 6 weeks (clinically healed). The swelling (edema) of the operated area was gone in 3 weeks in 11 patients $(78 \%)$ and in 6 weeks in the rest. The movements of the joints in the operated regions were slightly restricted, due to the superficial scar tissue formations, but that did not disturb the functions at all.

Biographic results: Radiographically, no angulation or dislocation was seen between the fixated fragments in any patients. The thickness of the physeal plate seemed to increase compared to the postoperative radiographs in 4 cases $(28 \%)$ during the first 3 weeks and to decrease in 3 cases $(21 \%)$ in 6 weeks. One case, the fracture of the femoral head, showed premature closure of the physeal plate compared to the contralateral physeal plate of the opposite limb. In the rest of the cases $(93 \%)$ the fixated physeal plates showed almost a normal closure. Callus formation could be seen in 9 cases (64\%), but it did not cross the growth plate. A slight decrease of the bone radiodensity around the implant could be seen in 4 cases (28\%) and an increase also in 4 cases. From the radiographs taken at the final examination of the operated distal femoral physeal fractures and the contralateral ones a decrease in the length of the injured bones was measured in 5 out of 6 cases. The average shortening was $4.5 \%$. No measurable difference was found in 1 dog (case number 8). One cat with this type of injury had disappeared and did not come to the final control. No changes indicating infection, secondary joint disease or ther pathological reactions could be seen in any case (Fig. 2).

\section{Discussion}

Since the study was to be the first clinical application of biodegradable implants in fixations of physeal fractures of cats and dogs a preclinical study seemed to be necessary. The physeal fractures of the distal femur being the most common physeal injuries in small animals (Hardie \& Chamber 1984) the same lesion was experimentally made in 4 cats. 

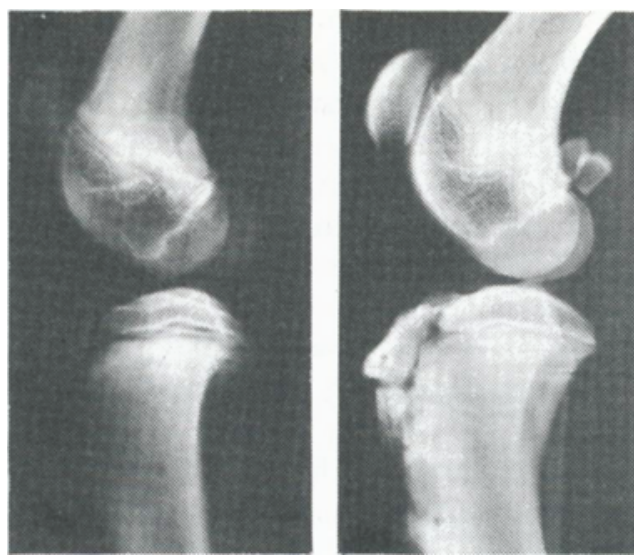

Figure 2.

Physeal fracture of the tibial crest of a borzoi. Radiographs before (a), three weeks (b) and eleven weeks (c) after the fixation with a 2 mm biorod.

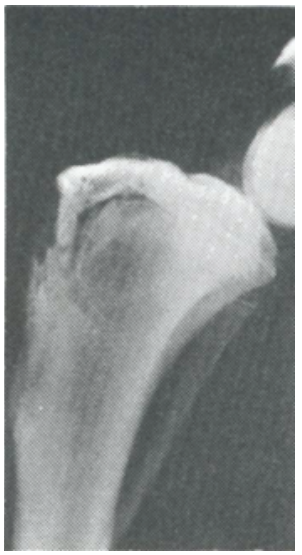

The excellent results of the rapid stabilisation of the fragments and the continued growth of the bone were sufficiently encouraging to give cause for clinical study on family pets with traumatic physeal injuries.

The distribution of different physeal fractures in this study followed the tendency published earlier (Salter \& Harris 1963, Marretta \& Schrader 1983). All the patients in this study had traumatic causes for their physeal fractures and the mechanisms and the age of the animals were similar to the biomechanics described by Braden 1981. According to the Salter classification of physeal fractures this study included only type I and II. This distribution agrees with the four-year retrospective study of physeal fractures made in the Animal Medical Center in New York (Marretta \& Schrader 1983). In this study salter IV fractures of the lateral humeral condyles were classified as metaphyseal fractures due to their nature of healing (Cockett \& Jones 1985). The Salter $\mathrm{V}$ type of physeal fractures of the distal ulna were also excluded from this group because they most often have pathological origin and need no fixation (Braden 1981).

The time between the injury and the operation should be as short as possible because the active growth cartilage reacts very quickly and exact reduction will be progressively difficult (Salter \& Harris 1963). Most fixations in this study were made within $24 \mathrm{~h}$ after the accident, and the rest within 3 days.

It is essential in the treatment of physeal fractures to achieve an exact reduction by handling the fragments gently and fixating them firmly. This fixation has to stay unchanged for 3-4 weeks, to get a good prognosis (Salter \& Harris 1963, Brinker et al. 1984 and Hardie \& Chambers 1984). In small animals this has to be done by open reduction and internal fixation because the closed treatment with splints and plaster casts will often fail for various reasons (Sittnikow 1982).

The conventional methods of fixating physeal fractures with metal implants of various systems and shapes will achieve a stable fixation of the fragments but most often they will lead to the premature closure of the growth plate and thus to the reduction of the length of the operated bone unless the implants are removed in a second operation 3-4 weeks after the fixation (Campbell et al. 1959 and Brinker et al. 1984). In this study the reduction could be sustained with biodegradable selfreinforced PGA implants 
(Biofix ${ }^{(B)}$ ) because they stick to the walls of the drilled channels very firmly. The minimal retarding effect on the growth in these fixations was caused by the power of the growing physeal plate being big enough to break the partly biodegraded PGA implants 3-4 weeks after the fixations. The gap between the ends of the broken implant was then filled with regenerative growth cartilage and not with bridging bone tissue, which does not effect the growth of the bone (Mäkelä et al. 1987).

The minor shortening effect of the fixations in the preclinical study (1.2\%) compared to the clinical one $(4.5 \%)$ was evidently due to the diameter of the implants. The biorods of $1 \mathrm{~mm}$ in diameter broke more easily than the biorods of $3.2 \mathrm{~mm}$. The power of the growth potential in the distal femur of the dog (case nr 8) was big enough to break the biodegrading implant of $3.2 \mathrm{~mm}$ in three weeks and there was no shortening of the operated limb while the growing cats did not succeed with that early enough and showed a small arrest of the growth.

The clinical effect of shortened bones in animals is minimal to none compared to man because animals will compensate slightly shortened legs using their limbs in semiflexed position when they walk and run (Berzon 1980).

\section{Conclusions}

The method of fixating physeal fractures with biodegradable implants made of selfreinforced polyglycolic acid (PGA) is very useful in small animal practice. The operative procedure is equal to the conventional one with metal implants and it demands only one special instrument (applicator) besides the normal orthopaedic instrument set. This implant has similar fixating properties compared to different metal ones used in physeal fractures. Unlike conventional methods the use of thin biorods ensures that the implants will biodegrade and break in 3-4 weeks and therefore need no secondary operation to remove them. Since they break at the level of the physeal plate their retarding effect on the growth is minimal.

\section{References}

Arnoczky SP: Muscosceletal System. In: Textbook of Small Animal Surgery. Slatter DH (ed.). WB Saunders Co. Philadelphia, Section XVIII 1985, 1926-2286.

Axelson PB, Räihä J, Mero M, Vainionpää $S$, Törmälä $P$, Rokkanen $P$ : The use of a biodegradable implant in fracture fixation. A review of literature and a report of two clinical cases. J. Small Anim. Pract. 1988, 29, 249-255.

Axelson PB, Räihä J, Sittnikow K, Skutnabb K, Mero M, Vainionpää $S$, Törmälä $S$, Rokka nen $P$ : The use of biodegradable implants in fracture fixation of small animal cancellous bone fractures. Acta vet. scand. 1988 29, 469-476.

Berzon $J L$ : The classification and management of epiphyseal plate fractures. J. Amer. Anim. Hosp. Assoc. 1980, 16, 651-658.

Bojrab MJ (ed.): Current Techniques in Small Animal Surgery. 2nd ed. Lea \& Febiger, Philadelphia 1983.

Braden TD: Epiphyseal Injuries. In: Pathophysiology in Small Animal Surgery. Bojrab MJ (ed.). Lea \& Febiger, Philadelphia 1981, p. 528-533.

Brinker WO, Hohn RB, Prieur WD: Manual of Internal Fixation in Small Animals. SpringerVerlag, Berlin, Heidelberg, New York, Tokyo 1984.

Campbell JR, Grisolia A, Zanconato G: The effects produced in the cartilaginous epiphyseal plate of immature dogs by experimental surgical traumata. J. Bone Joint Surg. 1959, 41, 1221-1240.

Cockett PA, Clayton Jones DG: The repair of humeral condylar fractures in the dog: a review of seventy-nine cases. J. Small Anim. Pract. 1985, 26, 493-520. 
Goldner J: A modification of the masson trichromtechnique for routine laboratory purpose. Amer. J. Pathol. 1983, 14, 237-243.

Hardie EM, Chambers JN: Factors influencing the outcome of distal femoral physeal fracture fixation: A retrospective study. J. Amer. Anim. Hosp. Assoc. 1984, 20, 927-931.

Marretta SM, Schrader SC: Physeal injuries in the dog: A review of 135 cases. J. Amer. Vet. Med. Assoc. 1983, 182, 708-710.

Mäkelä EA, Vainionpää S, Vihtonen K, Mero $M$, Laiho J, Törmälä P, Rokkanen P: The effect of a renetrating biodegradable implant on the epiphyseal plate: An experimental study on growing rabbits with special regard to polyglactin 910. J. Pediatric Orthop. 1987, 7, 415 -420 .

Piermattei DL, Greeley RG: An Atlas of Surgical Approaches to the Bones of the Dog and Cat. 2. ed. WB Saunders Co., Philadelphia 1979.

Salter $R B$, Harris WR: Injuries involving the epiphyseal plate. J. Bone Joint Surg. 1963, 45, 587-622.

Schenk RK: Zur histologischen Verarbeitung von unentkalkten Knocken. (On histological processing of uncalcified bones). Acta anat. 1965, 60, 9-13.
Sittnikow K: Transfixation as treatment of closed radius-ulna fractures in dogs. Hellsten-offset, Helsinki 1982.

Törmälä P, Rokkanen P, Kilpikari J, Pätiälä $H$, Vainionpää S, Vihtonen K, Mero M: Apparails chirurgicaux. (Surgical instruments). Belgian Patent 1984, 900513.
Sammanfattning
Resorberbara implantat för fixation av fyseala frakturer hos hund och katt.
Fyseala frakturer hos 10 katter och 8 hundar fixe- rades med resorberbara implantat av polyglykol- syra (Biofix ). Fixationerna gav en tilräcklig stabilitet för att frakturerna skulle läka inom tre veckor, utan yttre stödförband. I en preklinisk undersökning framgick att tre till fyra veckor efter fixationerna brast implantaten p. g. a. tillväxtkraf- ten i benet. De uppkomna spalterna mellan im- plantatets ändar fylldes med regenererande brosk- vävnad och inte med överbryggande benvävnad. Sålunda inverkade inte fixationen av växtzonerna nämnvärt på benets tillväxt.
Ingen felaktig utveckling av det växande benet, infektioner eller andra patologiska reaktioner kun- de påvisas i detta kliniska materiel.

(Received April 22, 1988).

Reprints may be requested from: Per B. Axelson, Small Animal Clinic MEVET, Ulfsbyvägen 25, SF-00350 Helsingfors, Finland. 